\title{
Discovering Environmental Attitude and Lifestyle Segmentation of Green Consumers: a Conceptual Model for Research
}

\author{
*Ratchaneekorn Dansirichaisawat, Opal Suwunnamek \\ King Mongkut's Institute of Technology Lad Krabang, Bangkok, Thailand \\ *ratcha_dansiri@hotmail.com
}

\begin{abstract}
The primary purpose of this research is to reviews the literature on green consumers segments with different profiles. It utilizes two constructs-environmental attitude and lifestyle- in the context of electric appliances products in Thailand. This research employs an empirical study by means of the questionnaire survey method to verify the hypotheses. Data will be collected by random sampling from working aged male and female customers who purchased electric appliances. The data will be analyzed using factor analysis, cluster analysis, discriminant and ANOVA. The usefulness of this research was identifying groups of similar customers and potential customers; to prioritize the groups to address; to understand their behavior; and to respond with appropriate marketing strategies.
\end{abstract}

Keyword: Green marketing, Segmentation, Environmental attitude, Lifestyle

\section{Introduction}

Natural resources and environmental conservation become the important agenda of globalization and their impact from natural disaster increased in many areas and caused the loss of life and properties. The awareness of natural reserve becomes the important issue for not only environmentalist but also many people paid attentions to nature and environment increasingly. In addition, the environmental responsibility is important factor which organizations and business have to inspect organization operations how to be responsible in society and global. By this reasons, green products become a choice of entrepreneurs and organizations to make up good images (Chen \& Chai, 2010) which their evaluations of the readiness of green businesses were necessary. Thailand has been going to enter the green economic concept indicated in National Economic and Society since 6th issue to 11th issue (B.E.2555-2559) and the government policy promoted energy reduction and alternative energy usage continuously such as energy-saving the measure of energy reserve promotion by sticking green labels on electrical appliances showing the electrical efficiency, development of Energy Service Company (ESCO), motivation by tax measure and low interest loan and campaign of building sense of energy saving usage etc. Furthermore, Thailand had a few researches about green consumer products, even though electrical products played role in daily life. The important factors of successful social and business building are not complicated if the marketers are able to segmentation, and also state the development which meet with the target group. In addition, the profound study of green products consumer will provide the direction to build conservative market and urge to green society increasingly in the future. Therefore, the researcher would like to present the segmentation of green consumers of electrical appliances products. In the context of Thailand, the purposes of this research were to build the understanding of behavior, attitudes, customers' readiness and opportunities of conservative markets which will be guideline of forcing green products policy in lifestyle, promotion of friendly environment production and sustainable consumption in order to raise quality of life, safety and good health in the future.

\section{Literature Review}

Green marketing: In 1960, the new marketing philosophy was called "Green Marketing" which occurred from consumers' demand of friendly environment products (Awad, 2011) and later played the important role increasingly. Presently, consumers pay more attentions to environment and they are pleased to pay extra for ecologically friendly products including renewable products which can reduce the environment damage and ecologically compatible products (Laroche, Bergeron \& Barbaro-Forleo, 2001).Therefore, the marketing 
organizations had changed strategies by concentrating the benefits of consumers, community, social and business sustainability on the suitable steps of marketing activities, at the same time they did the researches which responded to consumers' satisfaction based on sustainable development by creating balance in three following aspects: profit and social and environment responsibilities. The green market became one choice for entrepreneurs which open the chance to do business by concerning to public benefits at the same time. The number of new segment of consumers was increasing and was very important to the business. Green marketing is the planning, developing and promoting products or service to respond the consumers' demands and satisfaction of customers with quality, price and service and also no negatively impact to environment (Jain \& Kaur, 2003; Papadopoulos, Karagouni, Trigkas \& Platogianni, 2010; Peattie \& Crane, 2005).Green marketing is a good chance for entrepreneurs to create innovation and advantageous competition in business (Kaufman, 1999; Laroche et al., 2001; Ottman, 1992; Vaccaro, 2009). In addition, it will build up positive images of its brand (Gura u \& Ranchhod, 2005; Johri \& Sahasakmontri, 1998; Pugh \& Fletcher, 2002). Hence, green marketing is considered as a challenging for marketers in new millennium (Jain \& Kaur, 2003; Murphy, 2005).

Demographic characteristics of Green consumers: The consumers have different needs and demands (Kotler \& Armstrong, 2001), so it is difficult to mixed design to respond every levels of consumers. The marketers tried to segment customers and group the customers with same demand and defined the market targeting in order to develop products and marketing program which respond to customer satisfaction (Kotler, 2000). There are two types of market segmentation including business-based or industrial market segmentation and consumer market segmentation (Kimiloglu, Nasir \& Nasir, 2010). Generally, market segmentation started from basic data to complicated data which the most popular segmentation criteria was demographic characteristics consisting of age, sex, occupation, income, size of family, religious, and nationality etc. Demographic factors to be one of the most influencing factors in environmental behavior (Kollmuss \& Agyeman, 2002; Memery, Megicks \& Williams, 2005), the basic characters, and size of target market as well as media type that can be utilized in achieving maximum efficiency (Kotler, 2000). Age was the basic variable in green marketing research in the past (D'Souza, Taghian, Lamb \& Peretiatkos, 2007; Jain \& Kaur, 2006; Roberts, 1996). From the previous literature review, the researcher found that most of friendly environment products consumers were young age, concerned to environmental problems and were the environmentalist (D’Souza et al., 2007; Dunlap, Van Liere, Mertig \& Jones, 2000; Gan, Wee, Ozanne \& Kao, 2008; Roberts, 1996) On the contrary, some researcher found that environmentalists were older age (Zimmer et al., 1994). Furthermore, they were found that age had no significance to green purchasing behavior (Arttachariya, 2012).

Sex was demographic invariable applied for environmental study (Kemmelmeier, Krol \& Kim, 2002; Xiao \& Dunlap, 2007). Many studies have shown significant differences between men and women in environmental attitudes (Chen \& Chai, 2010; Dietz, Kalof \& Stern, 2002; Tikka, Kuitunen \& Tynys, 2000). Many researcher found that female worried about environment (Laroche et al., 2001; Stern, Dietz \& Guagnano, 1995), men having more negative attitudes towards the environment compared to women (Tikka et al., 2000). Women were more likely to buy green products because they believe that the product was better for the environment (Mainieri, Barnett, Valdero, Unipan \& Oskamp, 1997). Moreover, since most environmentally relevant behavior takes place at home (e.g. saving of electricity, recycling etc.), and most of the household purchase is much more often done by females than by males, green purchasing may be a concept more relevant to females than males (Lee, 2009). On the other hand, Balderjahn (1998) found that male worried and realized the environment more than female and was pleased willing to pay more for products of pollution reduction of environment. The research by Lee, (2009) stated that male adolescents of Hong Kong scored significantly higher in self-identity in environmental protection. Recently, scholars have found gender difference in identity development through self-defining activities (Sharp, Coatsworth, Darlin, Cumsille \& Ranieri, 2007).However, some researcher found that no significance relationship between sex and environmental friendly consumption (Gan et al., 2008; Paço \& Raposo, 2009).

Many researcher studied the relation between income and environmental attitudes (Franzen \& Meyer, 2010; Gelissen, 2007; Haller \& Hadler, 2008; Marquart-Pyatt, 2008; Newell \& Green, 1997; Roberts \& Bacon, 1997; Zimmer, Stafford \& Stafford, 1994). They found that income variable related significance with environmental friendly consumption behavior, in other words, most of environmental friendly consumption consumers had 
high average income. This reason, they would be willing to pay more to support green products even though price was higher than normal products (Brunso, Scholderer \& Grunert, 2004; Chan, 1999; Zimmer et al., 1994). The previous study by Bloom and Sevilla, (2004) founded that level of income influences the willingness to pay marginally higher prices as a social responsibility towards the environment. Empirical studies in countries with low income per capita do not show any improvement in the willingness to spend more on eco-friendly products. Therefore, the income level moderates the relations between consumers behavior towards the environment with their willingness to consume ecofriendly products (Junaedi, 2012). Moreover, the results by Roitner-Schobesberger, Darnhofer, Somsook and Vogl, (2008) found that consumers with higher income and with a higher educational degree were more likely to have purchased organic food in the past. However, the research results by Laroache et al. (2001), Roberts and Bacon (1997) and Zimmer et al. (1994) were not supported. They argued that high income only open the opportunity for consumption, but were not the decision criteria that the high income consumers were the green consumers more than low income consumers. In addition, Gan et al., (2008) founded that income was not significant effect on the probability of consumers' green purchasing decision. In addition, education level was another factor related with the attention and behavior of environment (Hockett, McClafferty \& McMullin, 2004; Hopkins \& Powers, 2009; Newell \& Green, 1997). From the literature review, researchers were found that educational factors have played key role and high educated were the green consumers more than low level of education (Roberts, 1996; Schwartz \& Miller, 1991; Swinyard \& Smith, 2003; Zimmer et al., 1994). Hockett et al., (2004) also reported that the more highly educated individuals were more likely to behave pro-environmentally. Furthermore, Hopkins and Powers, (2009) found education groups with less education than a college degree tend to be more altruistic than college graduates or those that have completed postgraduate degrees. In contrast, some researchers were not confirmed that the high education consumers were green consumers (Straughan\& Roberts, 1999).

Attitude of green consumers: Psychology was the knowledge of study mind system, thinking system and behavior through scientific process such as perception, emotion, characteristic, behavior and relationship including the various human activities of life style. To understand personal and social behavior, psychology concept indicated that behavior occurred by causes and stimulation which activated or motivated to express different behavior through decision-making process which takes place inside the brain. The stimulation considered as a black box (abstract) and expressed output in the form of behavior (concrete) (Kotler \& Armstrong, 1997).The consumer behavior were complex for study and analysis. The previous research showed that the general criteria of demography and geography indicated green consumers basic characteristics were not enough, since the majority of green consumers wished to take part in minimizing the environmental impact. Psychological variable could be forecasted clearly the consciousness and attitudes towards environment including behavior of green consumers (Banerjee \& McKeage, 1994; Chan, 1999; Schlegelmilch, Bohlen \& Diamantopoulos, 1996). Therefore, the attitude was applied to evaluate the response to determine the satisfaction or dissatisfaction to something. Many researcher applied psychographic to define green consumers and explained the consumer behavior pattern (Chan, 1999; Fraj \& Martı'nez, 2006; Fraj, Martı́nez \& Montaner, 2005; Gilg, Barr \& Ford, 2005; Jayawardhena, Wright \& Dennis, 2007; Kimiloglu et al., 2010; Paço \& Raposo, 2009).

Lifestyle of green consumers: The theory-based lifestyle was the important psychological variable since the beginning 1950 (Anderson \& Golden, 1984; Ansbacher, 1976; Havinhurst \& Feigenbaum, 1959; Lazar, 1963), which could be indicated the individual lifestyle in the form of activities, interests and opinions about the interesting issue (Kotler, 2000). The individual lifestyle became the behavior effecting individual internal believes and indicated the specific characteristics (Yu, 2011).Lifestyle was the factor related with consumer behavior (Mowen\& Minor, 1998) which could be explained the consumer behavior more clearly than demographic variables or economic and social variables (Harcar \& Kaynak, 2008). Lifestyle was applied in many research (ie. segmentation of consumers by sustainable consumption activities) (Barr, Gilg \& Ford, 2006), introducing products and services of special or unique features. The study of target consumer behavior through lifestyles was important to marketing effectiveness and decision-making regarding marketing strategy (Duff, 2001).

The tool of lifestyle study consisted of activities, interests and opinions (AIO rating scale) presented by Wells and Tigert (Wells \&Tigert, 1971) and continuously developed. From literature review, it was found that AIO 
was the tool used to study specific product market and service to different marketing target (Brengman, Genuens, Weijters, Smith \& Swinyard, 2005; Brunso et al., 2004; Green, Cordell, Betz \& Distefano, 2006; Hsu \& Chang, 2008; Hur, Kim \& Park, 2010; Kumar \& Sarkar, 2008; Lin, 2003; Swinyard \& Smith, 2003). AIO was used to study and analyze the specific characteristic of consumer behavior of product selection (Ewing, Pinto, \& Soutar, 2001; Kaynak \& Kara, 2001) in order to understand better the consumer lifestyle on their consumption behavior (Kahle, Liu \& Watkins, 1992; Kaynak \& Kara, 2001).Green lifestyle was a style of life to be a part of natural resource reduction consumption or less, pollution reduction and self- conscious improvement from believe and activities (Ropke, 1999). A paradigm shift in luxurious consumption to environmental friendly consumption or sustainable consumption under the concept "the change of idea effects the change of lifestyle". From the prior research found that lifestyle was psychological factor related and effected the sustainable consumption (Axsen, TyreeHageman, \& Lentz, 2012)

Segmentation and characteristics of green consumers: The idea of marketing segmentation was the study of consumer behavior of different individual characteristics which included demand, purchasing power, purchasing habits, location, believes and culture including environmental friendly consumption, which this consumers group seek value of mind, society and environment at the same time. A few research studied segmentation of green product consumers market and reported about various types of green consumers. For instance, Kreidler and Joseph-Mathews, (2009) studied green consumers by criteria of attitudes and participation to sustainable involvement. The research result separated consumers to 4 groups, "True-Blue Green" had high attitudes and sustainable involvement, the consumers of this group was pleased to devote for sustainable development. "Lean green" had high participation but low sustainable involvement which could be said that the consumers of this group are pleased to join sustainable involvement activities without expenses. "Surface green" had attitudes to high sustainable involvement but low participation. The consumer group understood the idea of sustainable involvement but they thought that it was over to join sustainable activities or recycle. "Craven green" had attitudes of low sustainable involvement participation. The green idea was the interesting issue but the consumers needed the convenient and this group was lack of selfconfidence of change of their purchasing behavior and original lifestyle.

Natural Marketing Institute, (2009) Marketing Research Institute of Pensylvania segmented adult consumers in America by 5 groups according to lifestyles of health and sustainability (LOHAS). It found that the middleaged women group paid the most attentions to environment and had green behavior, well-education, marriage status, high income, health-product selection, health concentration, organic food consumption, natural resource conservation and sustainable renewal including supporting environmental project, water and electrical saving and cloth bag usage. They concerned the organization's environmental policy and like to buy green products through on line. "Naturalites" were the group who worried their health and paid attentions to environment especially self-effect. They did not have green behavior from social and environmental awareness or even the recycle was not important. They only would like to learn. "Driffers" were the biggest group who had green behavior because of popularity but they did not believe or understand really the environment. They believed the media information, did the activities such as energy saving but they did not take care of carbon. This group's incomes were in middle level. "Conventionals" were the group who had green behavior if they got the effective result from their practice, but they did not like to buy organics food or health products. Most of them were the middle-aged men and high income. "Unconcerned" were the men with high income, however they had lowers standard education and were the least environmental responsible.

Moreover, the research by Gilg et al. (2005) developed about the segmentation of green and sustainable life consumers. They were found that the consumers separated into 4 groups as follows: Committed environmentalists, Mainstream environmentalists, Occasional environmentalist, and Non environmentalists. The research of D'Souza, Taghian, and Lamb, (2004) separated Australian consumers into 6 groups categorized by population and lifestyle criteria as follows; Living Greens, Grudging Greens, Lip service greens, Light Brown Battlers, and Brown Bombers. In addition, the research by Leinberger (2001) found that the American consumers were segmented to 5 groups with different environmental concern. They were called True-Blue, Greens, Greenback, Greens, Spouts, and Basic Browns. 
Research framework: The research aimed to present the green segmentation of electric appliance products in the context of Thailand by demography, environmental attitudes and lifestyle. The research framework was shown in Fig.1.

\section{Figure 1: The research framework of green segmentation}

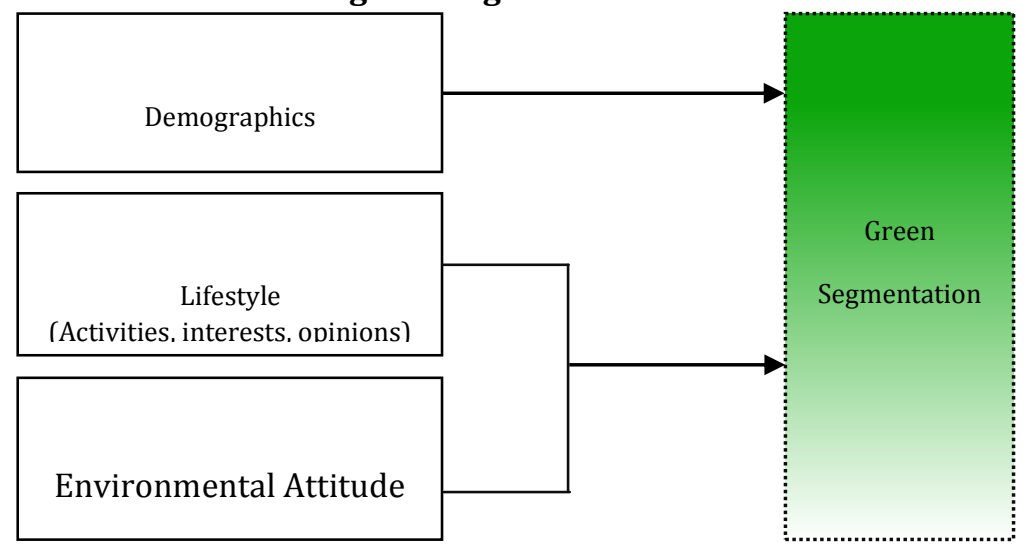

\section{Methodology}

Data collection: The kind of research was survey research and one-shot descriptive study. The tool of collection data was questionnaires and sampling by non-probability sampling. The data was collected from 400 electrical buyers who ages were between 15-60 years. The data was analyzed by Statistical Package for Social Science (SPSS) and applied factor analysis, cluster analysis, discriminant and ANOVA. The instruments of collection data in this research were close-ended questions, and the five-point Likert scale. The questionnaires separated into 3 parts; the first part measured demographic characteristics with 4 items consisting of gender, age, education level (undergraduates, graduates and postgraduate) and income, the second part surveyed lifestyle and the third part measured environmental attitudes.

Statistical analysis: The research was conducted with a pilot test of 30 respondents before the actual questionnaire was distributed. Cronbach's Alpha was used to examine the internal reliability of the pilot test. According to Malhotra, Hall, Shaw, and Oppenheim, (2002), reliability was considered weak when alpha coefficient was lower than 0.6 . If the alpha coefficient scores in the range of 0.6 to 0.8 , it is considered as being moderately strong. Lastly, if the alpha coefficient was in the range of 0.8 to 1.0 , it is considered very strong. Cluster analysis is a type of data classification carried out by separating the data into groups. The aim of cluster analysis is to categorize $n$ objects in $k(k>1)$ groups, called clusters, by using $p(p>0)$ variables. The distance or similarity value of a pair cases is calculated. Cluster analysis is frequently applied in market segmentation research (Jayawardhena et al., 2007; Kimiloglu et al., 2010). In marketing, discriminant analysis was once often used to determine the factors which distinguish different types of customers and/or products on the basis of surveys or other forms of collected data. Discriminant is the technique of distinguish objects from 2 or more groups which the similar objects will be grouped in one group and different objects will be grouped in different group by classifying from factors or variables forecasted the different results. There may be 1 or more 2 objects of independent variable caused different case in order to create linear correlation. Discriminant function or Fisher's discriminant function predicted a new case without group (Fisher, 1936).

\section{Conclusion}

This research contributed to present the green segmentation and collected data by questionnaires. The beneficial researches were 1) to understand better about the consumer behavior and readiness of each group. 2) to be guideline of the conservative market creation and run the efficient strategy by marketing mix (product price place and promotion). 3) to use as the data base of government policy and concerned organizations to drive the environmental friendly production and sustainable consumption. 
Acknowledgment: The authors would like to thank Dr. ChalitaSrinuan, Administration and management college, King Mongkut's Institute of Technology Ladkrabang, Thailand, for providing constructive comments on an earlier version of this paper.

\section{References}

Anderson, W. T. \& Golden, L. L. (1984). Lifestyle and psychographics: a critical review and recommendation. in Kinnear, T.C. (Ed.), Advances in Consumer Research, Association for Consumer Research, Provo, UT, 11, 405-411.

Ansbacher, H. L. (1976). Life style: a historical and systematic review. Journal of Individual Psychology, 23(1), 191-212.

Arttachariya, P. (2012). Environmentalism and Green Purchasing Behavior: A Study on Graduate Students in Bangkok, Thailand. Assumption University.

Awad, T. A. (2011). Environmental segmentation alternatives: buyers' profiles and implications. Journal of Islamic Marketing, 2(1), 55 - 73.

Axsen, J., TyreeHageman, J. \& Lentz, A. (2012). Lifestyle practices and pro-environmental technology. Ecological Economics, 82, 64-74.

Balderjahn, I. (1998). Personality variables and environmental attitudes as predictors of ecologically responsible consumption patterns. Journal of Business Research, 17, 51-56.

Banerjee, S. \& McKeage, K. (1994). How green is my value: exploring the relationship between environmentalism and materialism. In A. i. C. Research (Ed.), in Allen, C.T. and John, D.R (Vol. 21): Association for Consumer Research, Provo, UT.

Barr, S., Gilg, A. W. \& Ford, N. J. (2006). Sustainable lifestyles: Framing environmental action in and around the home. Geoforum, 37, 906-920.

Bloom, D. E. \& Sevilla, J. (2004). Willingness to Pay for Environmental Quality: Testable Empirical Implications of the Growth and Environment Literature: Comment. The B.E. Journal of Economic Analysis \& Policy, 3(1).

Brengman, M., Genuens, M., Weijters, B., Smith, S. M. \& Swinyard, W. R. (2005). Segmenting internet shoppers based on their web-usage-related lifestyles: a cross-cultural validation. Journal of Business Research, $58,79-88$.

Brunso, K., Scholderer, J. \&Grunert, K. G. (2004). Closing the gap between values and behavior-a means-end theory and lifestyle. Journal of Business Research, 57, 665-678.

Chan, R. Y. K. (1999). Environmental attitudes and behavior of consumers in China: survey findings and implications. Journal of International Consumer Marketing, 11(4), 25-52.

Chen, T. B. \& Chai, L. T. (2010). Attitude towards the Environment and Green Products: Consumers' Perspective. Management Science and Engineering, 4(2), 27-39.

D'Souza, C., Taghian, M. \& Lamb, P. (2004). A review of the green customers' perception formation about environmentally safe products. Paper presented at the ANZMAC 2004 Conference, School of Marketing and International Business, University of Wellington, Wellington, New Zealand.

D’Souza, C., Taghian, M., Lamb, P. \&Peretiatkos, R. (2007). Green decisions: demographics and consumer understanding of environmental labels. International Journal of Consumer Studies, 31(4), 371-376.

Dietz, T., Kalof, L. \& Stern, P. C. (2002). Gender, values and environmentalism. Social Science Quarterly, 83(1), 353-364.

Duff, M. (2001). Denim category evolves under life-style influence. Design Retailing Today, 40(8), 25-26.

Dunlap, R., Van Liere, K., Mertig, A. \& Jones, R. (2000). Measuring endorsement of the new ecological paradigm: a revised NEP scale. Journal of Social Issues, 56(3), 425-442.

Ewing, M. T., Pinto, T. M. \& Soutar, G. N. (2001). Agency-client chemistry: demographic and psychographic influences. International Journal of Advertising, 20(2), 169-187.

Fisher, R. A. (1936). The Use of Multiple Measurements in Taxonomic Problems. Annals of Eugenics, 7(2), 179-188.

Fraj, E. \& Martı́nez, E. (2006). Environmental values and lifestyles as determining factors of ecological consumer behavior: an empirical analysis. Journal of Consumer Marketing, 23(3), 133-144.

Fraj, E., Martı́nez, E. \& Montaner, T. (2005). Explaining ecological product purchase using consumers' psychographic characteristics. Unpublished Advances in Doctoral Research in Management. 
Franzen, A. \& Meyer, R. (2010). Environmental attitudes in cross-national perspective: a multilevel analysis of the ISSP 1993 and 2000. European Sociological Review, 26(2), 219-234.

Gan, C., Wee, H. Y., Ozanne, L. \& Kao, T. H. (2008). Consumers' purchasing behavior towards green products in New Zealand. Innovative Marketing, 4(1), 93-102.

Gelissen, J. (2007). Explaining popular support for environmental protection: a multilevel analysis of 50 nations. Environment and Behavior, 39(3), 392-415.

Gilg, A., Barr, S. \& Ford, N. (2005). Green consumption or sustainable lifestyles? Identifying the sustainable consumer. Future, 37, 481-504.

Green, G. T., Cordell, H. K., Betz, C. J. \& Distefano, C. (2006). Construction and validation of the National Survey on Recreation and the Environment's lifestyles scale. Journal of Leisure Research, 38(4), 513-535.

Gura u, C. \& Ranchhod, A. (2005). International green marketing: a comparative study of British and Romanian firms. International Marketing Review, 22(5), 547-561.

Haller, M. \& Hadler, M. (2008). Dispositions to act in favor of the environment: fatalism and readiness to make sacrifices in cross-national perspective. Sociological Forum, 23(2), 281-311.

Harcar, T. \& Kaynak, E. (2008). Life-style orientation of rural US and Canadian consumers: Are regio-centric standardized marketing strategies feasible? Asia Pacific Journal of Marketing and Logistics, 20(4), 433 -454 .

Havinhurst, R. J. \& Feigenbaum, K. (1959). Leisure and life style. American Sociologist, 64(1), 396-404.

Hockett, K. S., McClafferty, J. A. \& McMullin, S. L. (2004). Environmental concern, resource stewardship, and recreational participation: A review of the literature Blacksburg, VA: Virginia Polytechnic Institute and State University, College of Natural Resources,Conservation Management Institute.

Hopkins, R. A. \& Powers, T. L. (2009). Development and test of new dimensions of altruistic buying behavior. Journal of Consumer Marketing, 26(3), 185 - 199.

Hsu, J. L. \& Chang, K. M. (2008). Purchase of clothing and its linkage to family communication and lifestyles among young adults. Journal of Fashion Marketing and Management, 12(2), 147-151.

Hur, W. M., Kim, H. K. \& Park, J. (2010). Food and situation-specific lifestyle segmentation of kitchen appliance market. British Food Journal, 112(3), 294-312.

Jain, S. K. \& Kaur, G. (2003). Strategic green marketing: how should business firms go about adopting it? The Indian Journal of Commerce, 55(4), 1-16.

Jain, S. K. \& Kaur, G. (2006). Role of socio-demographics in segmenting and profiling green consumers: an exploratory study of consumers in India. Journal of International Consumer Marketing, 18(3), 107117.

Jayawardhena, C., Wright, L. T. \& Dennis, C. (2007). Consumers online: intentions, orientations and segmentation. International Journal of Retail \& Distribution Management, 35(6), 515-526.

Johri, L. M. \& Sahasakmontri, K. (1998). Green marketing of cosmetics and toiletries in Thailand. Journal of Consumer Marketing, 15(3), 265-281.

Junaedi, S. (2012). The Role of Income Level in Green Consumer Behavior: Multigroup Structural Equation Model Analysis. Paper presented at the 2012 International Conference on Business and Management 6 - 7 September Phuket - Thailand.

Kahle, L. R., Liu, R. \& Watkins, H. (1992). Psychographic variation across United States geographic regions. Advances in Consumer Research, 19, 346-352.

Kaufman, L. (1999). Selling green: what managers and marketers need to know about consumer environment attitudes. Environmental Quality Management, 8(4), 11-20.

Kaynak, E. \& Kara, A. (2001). An examination of the relationship among customer lifestyles, ethnocentrism, knowledge structures, attitudes and behavioral tendencies. International Journal of Advertising, 20(4), 457-482.

Kemmelmeier, M., Krol, G. \& Kim, Y. (2002). Values, economics, and pro-environmental attitudes in 22 societies. Cross-Cultural Research, 36(3), 256-285.

Kimiloglu, H., Nasir, V. A. \& Nasir, S. (2010). Discovering behavioral segments in the mobile phone market. Journal of Consumer Marketing, 27(5), 401 - 413.

Kollmuss, A. \& Agyeman, J. (2002). Mind the gap: why do people act environmentally and what are the barriers to pro-environmental behavior? Environmental Education Research, 8(3), 239-260.

Kotler, P. (2000). Marketing management (10 ed.). U.S.A: Prentice Hall.

Kotler, P. \& Armstrong, G. (1997). Marketing: An introduction (4 ed.). Upper Saddle River, NJ: Prentice-Hall.

Kotler, P. \& Armstrong, G. (2001). Principles of marketing (9 ed.). New Jersey: Prentice Hall Inc. 
Kreidler, N. B. \& Joseph-Mathews, S. (2009). How green should you go? Understanding the role of green atmospherics in service environment evaluations. International Journal of Culture Tourism and Hospitality Research, 3(3), 228 - 245.

Kumar, R. V. \& Sarkar, A. (2008). Psychographic segmentation of Indian urban consumers. Journal of Asia Pacific Economy, 13(2), 204-221.

Laroche, M., Bergeron, J. \& Barbaro-Forleo, G. (2001). Targeting consumers who are willing to pay more for environmentally friendly products. Journal of Consumer Marketing, 18(6), 503-520.

Lazar, W. (1963). Life style concepts and marketing. in Stephen, A.G. (Ed.), Toward Scientific Marketing, American Marketing Association, Chicago, IL, 143-151.

Lee, K. (2009). Gender differences in Hong Kong adolescent consumers' green purchasing behavior. Journal of Consumer Marketing, 26(2), 87 - 96.

Leinberger, P. (2001). Roper Green Gauge 2000. Paper presented at the Sixth National Green Power Marketing Conference, Portland Oregon.

Lin, F. Y. (2003). An analysis of hospitality consumer lifestyles in the United States. Texas Tech University, Lubbock, TX.

Mainieri, T., Barnett, E., Valdero, T., Unipan, J. \& Oskamp, S. (1997). Green buying: The influence of environmental concern on consumer behavior. Journal of Social Psychology, 137, 189-204.

Malhotra, N., Hall, J., Shaw, M. \& Oppenheim, P. (2002). Marketing Research an Applied Orientation (2 ed.): Prentice Hall.

Marquart-Pyatt, S. (2008). Are there similar influences on environmental concern?: comparing industrialized countries. Social Science Quarterly, 89(5), 1-24.

Memery, J., Megicks, P. \& Williams, J. (2005). Ethical and social responsibility issues in grocery shopping: a preliminary typology. Qualitative Market Research: An International Journal, 8(4), 399-412.

Mowen, J. C. \& Minor, M. (1998). Consumer Behavior (5 ed.). NJ: Prentice-Hall, Upper Saddle River.

Murphy, P. E. (2005). Sustainable marketing. Business \& Professional Ethics Journal, 24(1/2), 71-198.

Newell, S. J. \& Green, C. L. (1997). Racial differences in consumer environmental concern. The Journal of Consumer Affairs, 31(1), 53-69.

NMI, N. M. I. (2009). NMI announces new LOHAS consumer segments, The LOHAS Consumer Trends Database (Publication. Retrieved January 2, 2013: http://www.nmisolutions.com/lohasd

Ottman, J. A. (1992). Industry's Response to Green Consumerism. Journal of Business Strategy, 13(4), 3 - 7.

Paço, A. D. \& Raposo, M. (2009). Green segmentation: an application to the Portuguese consumer market. Marketing Intelligence \& Planning, 27(3), 364-379.

Papadopoulos, I., Karagouni, G., Trigkas, M. \& Platogianni, E. (2010). Green marketing: The case of Greece in certified and sustainably managed timber products. EuroMed Journal of Business, 5(2), 166-190.

Peattie, K. \& Crane, A. (2005). Green marketing: legend, myth, farce or prophecy?", Qualitative Market Research. An International Journal, 8(4), 357-370.

Pugh, M. \& Fletcher, R. (2002). Green international wine marketing. Australasian Marketing Journal, 10(3), 7685.

Roberts, J. A. (1996). Green consumers in the 1990s: profile and implications for advertising. Journal of Business Research, 36(3), 217-231.

Roberts, J. A. \& Bacon, D. R. (1997). Exploring the subtle relationships between environmental concern and ecologically conscious consumer behavior. Journal of Business Research, 40(1), 79-89.

Roitner-Schobesberger, B., Darnhofer, I., Somsook, S. \& Vogl, C. (2008). Consumers' perception of organic foods in Bangkok. Thailand. Food Policy, 33(2), 112-121.

Ropke, I. (1999). The Dynamics of Willingness to Consume. Ecological Economics, 28, 399-420.

Schiffman, L. G. \& Kanuk, L. L. (2007). Consumer behavior (9 ed.). Upper Saddle River, NJ: Prentice Hall.

Schlegelmilch, B., Bohlen, G. M. \& Diamantopoulos, A. (1996). The link between green purchasing decisions and measures of environmental consciousness. European Journal of Marketing, 30(5), 35-55.

Schwartz, J. \& Miller, T. (1991). The earth's best friends. American Demographics, 13, 26-35.

Sharp, E. H., Coatsworth, J. D., Darlin, N., Cumsille, P. \& Ranieri, S. (2007). Gender differences in the selfdefining activities and identity experiences of adolescents and emerging adults. Journal of Adolescence, 30(2), 251-269.

Stern, P., Dietz, T. \& Guagnano, G. (1995). The new ecological paradigm in social-psychological context. Environment and Behavior, 27, 723-743. 
Straughan, R. D. \& Roberts, J. A. (1999). Environmental segmentation alternatives: a look at green consumer behavior in the new millennium. Journal of Consumer Marketing, 16(6), 558-575.

Swinyard, W. R. \& Smith, S. M. (2003). Why people (don't) shop online: a lifestyle study of the internet consumer. Psychology \& Marketing, 20(7), 567-597.

Tikka, P., Kuitunen, M. \& Tynys, S. (2000). Effects of educational background on students' attitudes, activity levels, and knowledge concerning the environment. Journal of Environmental Education, 31, 12-19.

Vaccaro, V. L. (2009). B2B green marketing and innovation theory for competitive advantage. Journal of Systems and Information Technology, 11(4), 315-330.

Wells, W. \& Tigert, D. (1971). Activities, interests, and opinions. Journal of Advertising Research, 11, 27-35.

Xiao, C. \& Dunlap, R. (2007). Validating a comprehensive model of environmental concern cross-nationally: a US-Canadian comparison. Social Science Quarterly, 88(2), 471-493.

Yu, C. S. (2011). Construction and validation of an e-lifestyle instrument. Internet Research, 21(3), 214 - 235.

Zimmer, M. R., Stafford, T. F. \& Stafford, M. R. (1994). Green issues: dimensions of environmental concern. Journal of Business Research, 30(1), 63-74. 